Review

\title{
Angiogenesis in pancreatic ductal adenocarcinoma: A controversial issue
}

\author{
Vito Longo ${ }^{1, *}$, Oronzo Brunetti ${ }^{2, *}$, Antonio Gnoni ${ }^{3}$, Stefano Cascinu ${ }^{4}$, Giampietro \\ Gasparini ${ }^{5}$, Vito Lorusso ${ }^{2}$, Domenico Ribatti ${ }^{6,7}$ and Nicola Silvestris ${ }^{2}$ \\ ${ }^{1}$ Department of Medical Oncology, Hospital of Taranto, Taranto, Italy \\ 2 Medical Oncology Unit, Cancer Institute "Giovanni Paolo II", Bari, Italy \\ 3 Department of Medical Oncology, Hospital "Vito Fazi" of Lecce, Lecce, Italy \\ ${ }^{4}$ Medical Oncology Unit, University of Modena, Modena, Italy \\ ${ }^{5}$ Scientific Direction, Cancer Institute "Giovanni Paolo II", Bari, Italy \\ ${ }^{6}$ Department of Basic Medical Sciences, Neurosciences and Sensory Organs, University of Bari Medical School, Bari, Italy \\ 7 National Cancer Institute "Giovanni Paolo II", Bari, Italy \\ * These authors have contributed equally to this work \\ Correspondence to: Nicola Silvestris, email: n.silvestris@oncologico.bari.it \\ Keywords: angiogenesis, pancreatic ductal adenocarcinoma, hypoxia, desmoplastic reaction \\ Received: May 27, $2016 \quad$ Accepted: July 13, $2016 \quad$ Published: July 21, 2016
}

\section{ABSTRACT}

Pancreatic ductal adenocarcinoma (PDAC) occurs in the majority of cases with early loco-regional spread and distant metastases at diagnosis, leading to dismal prognosis with a 5 -year overall survival rate moderately over than $5 \%$. This malignancy is largely resistant to chemotherapy and radiation, but the reasons of the refractoriness to the therapies is still unknown. Evidence is accumulating to indicate that the PDAC microenvironment and vascularity strongly contribute to the clinical features of this disease. In particular, PDAC is characterized by excessive dense extracellular matrix deposition associated to vasculature collapse and hypoxia with low drug delivery, explaining at least partly the low efficacy of antiangiogenic drugs in this cancer. Strategies aimed to modulate tumor stroma favoring vasculature perfusion and chemotherapeutics delivery are under investigation.

\section{INTRODUCTION}

Pancreatic ductal adenocarcinoma (PDAC) is characterized by a low microvascular density (MVD) as compared to other tumor types [1]. Therefore, hypoxia inducible factor 1 alpha (HIF-1 $\alpha$ ) and vascular endothelial growth factor-A (VEGF-A) expression is increased and correlates with poor prognosis [2-3]. Another typical feature of PDAC is the presence of an intense fibroinflammatory reaction, namely desmoplastic reaction (DR), responsible of an high intratumoral pressure and solid stress causing vasculature collapse $[1,4]$.

However, even though the anti-angiogenic treatments improved survival in subcutaneous and orthotopic pre-clinical models, the same treatments resulted ineffective in genetically engineered mouse models (GEMMs) of PDAC, as well as in clinical trials [5]. Differently from the transplantable models that have low stroma and pancreatic cancer cells (PCCs) are close to the vessels, GEMMs and human PDAC are characterized by a dense stroma, which is responsible of a high interstitial pressure and collapsed vessels with and impaired drug delivery.

This review will focus on the peculiar tumor angiogenesis and microenvironment in PDAC, and on the effects of these findings on the efficacy of anti-angiogenic clinical trials.

\section{ANGIOGENESIS AND TUMOR MICROENVIRONMENT IN PDAC}

Different studies have demonstrated a relationship between microvascular density (MVD), tumor VEGF-A levels, and disease progression in PDAC [610]. The functional analysis of the tumor vasculature 
has demonstrated that vessels appear collapsed as a consequence of high interstitial pressure with a low delivery of small molecules $[1,4]$. PDAC is characterized by a fibro-inflammatory reaction, namely DR, which consists in an abundant deposition of dense collagen types I and III bundles, hyaluronic acid and fibronectin, loss of basement membrane integrity, and invasion of malignant cells into the interstitial matrix associated with a disorganized vasculature characterized by vessels with variable diameters, abnormal multiple branching and disrupted interendothelial junctions [11-13].

DR is the result of a complex interplay between pancreatic stellate cells (PSCs) and PCCs. Co-colture of these two types of cells or the incubation of PCCs with PSCs supernatants results in a significant increase of release of endostatin by PCCs. Moreover, both PSCs and PCCs produce matrix metalloproteinase-12 (MMP-12) and cathepsin B to cleave endostatin from collagen XVIII. Endostatin increases hypoxia levels by inhibiting the angiogenesis and at the same time stimulates the secretion of MMPs by PSCs [14].

This hypoxic microenviroment, not only contributes to pro-fibrogenic activity of PSCs but stimulates PSCs to produce several angiogenic molecules, including VEGF, fibroblast growth factor-2 (FGF-2), platelet derived growth factor (PDGF), interleukin-8 (IL-8), MMP-9, and vasohibin-1, resulting in foci of angiogenesis in the peripheral areas of the tumor [14-15] (Figure 1). High levels of HIF- $\alpha$ increases, in turn, VEGF-A expression, and HIF-1 $\alpha$ and VEGF-A not only contribute to PDAC aggressiveness by angiogenesis but also by a direct stimulation of tumor cell proliferation and metastatic capacity [2-3]. Stimulation of tumor cell proliferation and metastatic capacity through the regulation of the expression of actin-bundling proteins, MMPs and chemokine receptors, also occurs [16]. Furthermore, in PDAC other mitogenic and pro-angiogenic growth factors are over-expressed including transforming growth factor beta (TBF- $\beta$ ), hepatocyte growth factor, epidermal growth factor, and insulin like growth factor [17]. In particular, once activated, TGF- $\beta$ receptors phosphorylate SMAD proteins to form complexes with transcription factor SMAD4, involved in the regulation of several genes which control angiogenesis and extracellular matrix remodeling [18].

\section{INFLAMMATION IN PDAC}

Inflammatory cells contribute to the proliferative and invasive capacity of solid and hematological malignancies [19-21]. PDAC is characterized by an abundant inflammatory infiltration consisting in cancerassociated fibroblasts, macrophages, mast cells (MCs) and lymphocytes $[12,22]$. MCs are now recognized as critical components of tumor stromal microenvironment. They are more numerous in PDAC than in benign pancreatic pathology and, at the same time, they are more numerous in PDAC than in the normal adjacent tissue [22-23]. In addition, PDACs with elevated numbers of infiltrating MCs and high MVD have a worse prognosis [24-25]. PCCs induce MCs and macrophages migration releasing chemoattractant molecules, such as colony-stimulating factor-1 and chemokine ligand 2 [26]. MCs express proangiogenic factors as VEGF-A, FGF-2, PDGF, tryptase, chymase, and MMPs promoting tumor growth [27-28]. Moreover, MCs promote PSCs proliferation releasing IL13 and tryptase, and PSCs stimulate MCs proliferation [29].

Tumor-supportive M2-macrophages number is higher in PDAC than in benign pancreatic pathology and in normal tissue [22], and correlates with higher rate of metastasis and poor prognosis [30]. Inhibition of macrophage recruitment to the tumor microenvironment by targeting adhesion molecule integrin $\alpha 4 \beta 1$ or myeloid $\mathrm{PI} 3 \mathrm{~K} \gamma$ resulted in a marked decrease of blood vessel formation in pancreatic cancer models [31].

\section{GENES INVOLVED IN PDAC ANGIOGENESIS}

HIF-1 $\alpha$ G1790A and C1772T single nucleotide polymorphisms appeared more frequently in PDAC, predicting higher risk for its development [32]. HIF-1 $\alpha$ expression in PSCs results as a sensor of oxygen levels in pancreatic tissue, inducing an up-regulation of VEGF levels [15]. Moreover, PSCs improve angiogenesis by enhancing the levels of angiopoietin-1 and its receptor Tie-2 mRNA, both involved in the control of tumor angiogenesis, in PDAC microenvironment $[15,33]$.

Angiogenic gene signature has been assessed in PDAC analyzing the levels of 129 angiogenic genes from The Cancer Genome Atlas (TCGA). About 35\% of PDACs show an up-regulation of pro-angiogenic genes, including FGFR-1, and VEGFR-1, -2 and -3 , and of pro-inflammatory genes, such as IL-1B, IL-6, and JAK2, anti-inflammatory IL-10, as well as histone deacetylase-9, with a major involvement of TGF- $\beta$, which regulates the smad signal pathway [34]. Most of PDAC show loss of heterozygosity for SMAD4 locus, with $50 \%$ of PDAC having either homozygous deletion or mutational inactivation of the second allele. SMAD4 restoration inhibited both angiogenesis and extracellular matrix remodeling [18]. Conversely, SMAD4 re-expression in BxPC3 PCCs fails to suppress angiogenesis in vivo [35]. SMAD4 and nuclear SMAD4 expression correlates with high levels of CD31, the main endothelial cell-specific marker [34].

MicroRNAs (miRNA), play an important role in the regulation of gene expression in PDAC, including angiogenesis [36]. Hypoxia induces the expression of miRNA-21 in PDAC cells via HIF-1 $\alpha$ allowing cells to avoid apoptosis [37], at the same time miRNA-21 
acts as an inhibitor of endothelial cell proliferation and migration [38]. In a PDAC model, a lentiviral transported antimiRNA-21 improved tumor angiogenesis, improving the flow of gemcitabine with a synergistic antitumoral effect [39]. Whereas, MiR139 and miR200c resulted upregulated in primary endothelial cell cultures derived from PDAC patients, suggesting that they may improve tumor angiogenesis [40].

Although there has been some progress concerning angiogenesis gene signature in PDAC, the epigenetic regulation systems seem to be still poorly known, and might be used as a possible therapeutic target.

\section{PRE-CLINICAL ANTI-ANGIOGENIC APPROACHES IN PDAC}

Several Authors targeted VEGF signaling using nude mouse models of human PDAC. Injection of PDAC antisense VEGF-A gene cells into athymic nude mice lead to an $80 \%$ decrease of tumor growth compared with mice injected with control cells [41]. Engineerization of Panc-1 cells and PK-8 cells to produce a soluble form of the decoy receptor of VEGF, inoculated in SCID mice, resulted in a PDAC model with both low MVD and tumor growth [42]. Ziv-aflibercept, a VEGF-Trap, decreased tumor MVD and suppressed cancer cell proliferation in an orthotopic model of PDAC [43]. More recently, curcumin analogues UBS109 and EF31 downregulated angiogenic factors such as HIF-1 $\alpha$, Hsp90, COX-2 and VEGF in xenograft models of PDAC showing antitumor and anti-angiogenic effects [44]. LY294002 (a PI3K inhibitor) in combination with gemcitabine and ionizing radiation, inhibited cancer cell growth, metastasis and angiogenesis targeting PI3K/ MMPs/Ln-5 $\gamma 2$ signaling pathways in xenograft model in which vasculogenic mimicry occurs. [45]. Ginsenoside $\mathrm{Rg} 3$, a tetracyclic triterpenoid saponin, altered vasculogenic mimicry process in nude mouse xenografts of PDAC, downregulating the expression level of VEcadherin, EphA2, MMP-2 and MMP-9 mRNA [46]. The simultaneous target of TGF- $\beta$ R and JAK1 phosphorylase, using SB505124 and ruxolitinib suppressed endothelial activation in $3 \mathrm{D}$ co-cultures of PDAC and endothelial cells by suppressing proliferation and angiogenesis [34].

Experimental models are characterized by an high vascularity and the absence of desmoplastic reaction, as instead occurs in human PDAC. To avoid this pitfall, a GEMM of PDAC characterized by a dense stroma and collapsed vessels has been developed, using mutant Kras and p53 alleles in pancreatic cells (KPC) mice models [47]. In these models, sunitinib, targeting VEGF and PDGF receptors impair angiogenesis, but fail to reduce tumor burden [48]. Similarly, gemcitabine plus bevacizumab did not achieve a statistical increase of median (m) OS or progression free survival (PFS) [49].

As consequences of hypoperfusion, a reduced sensitivity to chemotherapy derives from a limitation of drug delivery due to reduced vascularization [1]. In this context, murine models have been developed in order to normalize the vasculature [50] or to reduce the pressure on the collapsed vessels, $[1,51]$. The small molecule LB100 , an inhibitor of phosphatase 2A (PP2A), increased MVD in the PDAC xenograft model resulting in a higher chemotherapeutics delivery with improvement of objective response [50].

A recombinant human hyaluronidase conjugated with polyethylene glycol has been used in KPC mice PDAC models with a reduction of intratumoral hyaluronan and a significant improvement of tumor perfusion without an increase of MVD favouring chemotherapeutic delivery. KPC mice treated with gemcitabine together with this drug or gemcitabine alone, show a significantly increased response and $\operatorname{mOS}$ [1]. In a parallel similar study, Jacobetz et al demonstrate that hyaluronidase leads to microenvironment changes in endothelium with an increase of vascular permeability drug permeability, and an increase of survival in KPC mice treated with gemcitabine [4]. IPI-926, a derivate of cyclopamine, targeting Hedgehog pathway by inhibiting Smo, reduced the collagen-1 content and destroyed tumor-associated desmoplastic tissue, increased the MVD and concentration of gemcitabine, in KPC mice model [51]. Nonetheless, in contrast with this last study, in a Kre PDAC mice model, both the Shh (Sonic Hedgehog, a peculiar ligand of Hedgehog pathway) gene delection and Hedgehog targeting through IPI-926, reduced stromal content, but generated more aggressive PDAC with a high proliferation rate and an increased vascularity [52]. Furthermore, administration of DC101, an antibody blockingVEGFR-2, in Shh-deleted mice, reduces tumor proliferation inducing tumoral necrosis through angiogenesis inhibition. Moreover, inhibition of desmoplasia with depletion of myofibroblasts, resulted in transgenic mice with shorter survival and invasive and aggressive PDAC [53].

Despite the fact that many attempts to reduce the stroma to normalize tumor vascularization led to interesting results in vivo, most recent data have highlighted how this approach lead to a more aggressive phenotype with a lower survival. In parallel, although classic anti-angiogenic molecules, such as bevacizumab and sunitinib, has failed to induce tumor regression, the use of alternative angiogenetic targets, such as SB505124 and ruxolitinib of TGF- $\beta$ type I receptor kinase and JAK1 phosphorylase, give more promising results in PDAC treatment.

\section{CLINICAL TRIALS OF ANTI- ANGIOGENIC THERAPY IN PDAC}

Several phase II and III clinical trials have been conducted in PDAC using anti-angiogenic inhibitors. On the basis of a multicenter phase II trial in patients with metastatic PDAC which achieved a $21 \%$ ORR and 
Table 1: Main clinical trials ongoing in PDAC targeting angiogenesis/stroma

\begin{tabular}{|c|c|c|c|c|c|}
\hline \multicolumn{6}{|c|}{ Targeting PDAC angiogenesis } \\
\hline Setting & Phase & Design & Mechanism of action & Primary endpoints & \begin{tabular}{|c|}
$\begin{array}{c}\text { Trial } \\
\text { identification } \\
\text { number }\end{array}$ \\
\end{tabular} \\
\hline I line & I & $\begin{array}{l}\text { Ruxolitinib plus gemcitabine plus nab- } \\
\text { paclitaxel }\end{array}$ & $\begin{array}{l}\text { Janus-associated kinase } 1 \text { (JAK1) and } \\
\text { JAK2 inhibition }\end{array}$ & Safety & NCT01822756 \\
\hline I line & I & $\begin{array}{l}\text { Gemcitabine plus nab-paclitaxel plus } \\
\text { GS-5745 }\end{array}$ & MMP9 inhibition & Safety & NCT01803282 \\
\hline I line & $\mathrm{I} / \mathrm{II}$ & $\begin{array}{l}5 \mathrm{FU} \text { plus nab-paclitaxel plus } \\
\text { bevacizumab plus calcium leucovorin } \\
\text { plus oxaliplatin }\end{array}$ & $\begin{array}{l}\text { Inhibition of vascular endothelial growth } \\
\text { factor A }\end{array}$ & $\begin{array}{l}\text { Dose limiting toxicities } \\
\text { (Phase } 1) \text {; } \\
1 \text { year survival rate } \\
\text { (Phase II) }\end{array}$ & NCT02620800 \\
\hline Resectable & II & $\begin{array}{l}\text { Gemcitabine plus bevacizumab plus } \\
\text { external beam radiotherapy } 3 \mathrm{~Gy} / \\
\text { fraction utilizing a } 95 \% \text { isodose field } \\
\text { over } 10 \text { consecutive weekdays }\end{array}$ & $\begin{array}{l}\text { Inhibition of vascular endothelial growth } \\
\text { factor A }\end{array}$ & $\begin{array}{l}\text { R0 resection rate/ rate } \\
\text { of complete pathologic } \\
\text { response after resection }\end{array}$ & NCT00557492 \\
\hline II line & II & Regorafenib plus gemcitabine & $\begin{array}{l}\text { Dual targeted VEGFR2-TIE2 tyrosine } \\
\text { kinase inhibition }\end{array}$ & PFS & NCT02383433 \\
\hline II line & II & Regorafenib & $\begin{array}{l}\text { Dual targeted VEGFR2-TIE2 tyrosine } \\
\text { kinase inhibition }\end{array}$ & PFS & NCT02080260 \\
\hline II line & II & Regorafenib & $\begin{array}{l}\text { Dual targeted VEGFR2-TIE2 tyrosine } \\
\text { kinase inhibition }\end{array}$ & $\begin{array}{l}\text { 2-months progression } \\
\text { free survival rate }\end{array}$ & NCT02307500 \\
\hline I line & II R & $\begin{array}{l}\begin{array}{l}\text { Gemcitabine plus TL118 vs } \\
\text { gemcitabine }\end{array} \\
\end{array}$ & $\begin{array}{l}\text { TL118 is a drug formed by four } \\
\text { molecules: cyclophosphamide, } \\
\text { diclofenac, sulfasalazine, and cimetidine, } \\
\text { angiogetic inhibitors through anti- } \\
\text { inflammatory mechanisms }\end{array}$ & Disease control rate & NCT01509911 \\
\hline I line & II R & mFOLFIRINOX plus ramucirumab & VEGF Receptor 2 inhibition & PFS & NCT02581215 \\
\hline $\begin{array}{l}\text { II line (after } \\
\text { gembitabine) }\end{array}$ & IIR & $\begin{array}{l}\begin{array}{l}\text { Capecitabine plus ruxolitinib vs } \\
\text { capecitabine }\end{array} \\
\end{array}$ & $\begin{array}{l}\text { Janus-associated kinase } 1 \text { (JAK1) and } \\
\text { JAK2 inhibition }\end{array}$ & OS & NCT01423604 \\
\hline II line & III & $\begin{array}{l}\text { Capecitabine plus ruxolitinib vs } \\
\text { capecitabine }\end{array}$ & $\begin{array}{l}\text { Janus-associated kinase } 1 \text { (JAK1) and } \\
\text { JAK2 inhibition }\end{array}$ & OS & NCT02119663 \\
\hline \multicolumn{6}{|c|}{ Targeting PDAC stroma } \\
\hline Setting & Phase & Design & Mechanism of action & Primary endpoints & \begin{tabular}{|c|}
$\begin{array}{c}\text { Trial } \\
\text { identification } \\
\text { number }\end{array}$ \\
\end{tabular} \\
\hline I line & I & mFOLFIRINOX plus IPI-926 & Hedgehog pathway inhibitor & $\begin{array}{l}\text { Maximum tolerated dose } \\
\text { (MTD) }\end{array}$ & NCT01383538 \\
\hline I line & I & PEGPH20 plus cetuximab & $\begin{array}{l}\text { Destruction of the stroma through the } \\
\text { cleavage of hyaluronan }\end{array}$ & Safety & NCT02241187 \\
\hline I line & I & $\begin{array}{l}\text { PEGPH20 } \\
\text { mFOLFIRINOX plus PEGPH20 vs } \\
\text { mFOLFIRINOX }\end{array}$ & $\begin{array}{l}\text { Destruction of the stroma through the } \\
\text { cleavage of hyaluronan }\end{array}$ & $\begin{array}{l}\text { MTD/safety } \\
\text { OS }\end{array}$ & NCT01959139 \\
\hline I line & II R & $\begin{array}{l}\text { PEGPH20 plus nabpaclitaxel plus } \\
\text { gemcitabine vs nabpaclitaxel plus } \\
\text { gemcitabine }\end{array}$ & $\begin{array}{l}\text { Destruction of the stroma through the } \\
\text { cleavage of hyaluronan }\end{array}$ & $\begin{array}{l}\text { PFS; } \\
\text { Evaluation of the } \\
\text { thromboembolic events }\end{array}$ & NCT01839487 \\
\hline $\begin{array}{l}\text { Borderline } \\
\text { resectable }\end{array}$ & II R & $\begin{array}{l}\text { Gemcitabine plus nab-paclitaxel plus } \\
\text { PEGPH20 vs gemcitabine plus nab- } \\
\text { paclitaxel }\end{array}$ & $\begin{array}{l}\text { Destruction of the stroma through the } \\
\text { cleavage of hyaluronan }\end{array}$ & $\begin{array}{l}\text { Pathologic complete } \\
\text { response; } \\
\text { Clinically } \\
\text { relevant pancreatic } \\
\text { fistula } \\
\end{array}$ & NCT02487277 \\
\hline I line & III & $\begin{array}{l}\text { Gemcitabine plus nab-paclitaxel plus } \\
\text { PEGPH20 vs gemcitabine plus nab- } \\
\text { paclitaxel }\end{array}$ & $\begin{array}{l}\text { Destruction of the stroma through the } \\
\text { cleavage of hyaluronan }\end{array}$ & $\begin{array}{l}\text { PFS } \\
\text { OS }\end{array}$ & NCT02715804 \\
\hline
\end{tabular}


a mOS of 8.8 months with the combination gemcitabine plus bevacizumab [54], Cancer and Leukemia Group B (CALGB) conduct a double-blind, placebo-controlled, randomized phase III trial of gemcitabine/bevacizumab versus gemcitabine/placebo in advanced PDAC. Five hundred and thirty-five patients were enrolled to receive gemcitabine at $1,000 \mathrm{mg} / \mathrm{m}^{2}$ over 30 minutes on days 1,8 , and 15 every 28 days and bevacizumab at $10 \mathrm{mg} /$ $\mathrm{kg}$ or placebo on days 1 and 15 every 28 days. In spite the promising results of the phase II trial, the addition of bevacizumab to gemcitabine did not improve mOS of 5.8 and 5.9 months, with a not statistically improved mPFS of 3.8 and 2.9 months for combination arm and gemcitabine alone arm, respectively. The only statistically significant differences in grades 3 and 4 toxicity regarded hypertension $(10 \% \mathrm{v} 3 \% ; P<.001)$ and proteinuria $(5 \%$ v $1 \% ; P=.002)[5]$. The Authors imputed the different results between the two phase trials to the different selection of patients, i.e. a better PS in the phase II study.

A subsequent study, with the aim to identify predictive biomarkers of response to bevacizumabcontaining regimen in PDAC has been conducted using serum from patients enrolled in the CALGB 80303 trial. One hundred and fifty-six proteins were quantified and authors selected histidine-rich glycoprotein (HRG) and complement factor $\mathrm{H}(\mathrm{CFH})$ as possible predictive markers. Unfortunately, there was no evidence for interaction with bevacizumab and $\mathrm{HRG}$, but there was some evidence for a weak positive correlation of HRG with OS $(\tau=0.11[0.03,0.19] ; P<.01)$. CFH was found to be neither a predictive nor a prognostic factor for OS [55]. Subsequently, on the same setting of patients, three markers predictive for bevacizumab response were identified: VEGF-D, SDF1, and Ang-2. In particular, low levels of VEGF-D were predictive to benefit from bevacizumab plus gemcitabine arm, whereas, below median levels of both Ang-2 and SDF1 predicted for greater benefit in the placebo group [56]. However, the same authors assert the need to evaluate these markers in a larger sample in order to select the highest number of positive and negative predictive markers of response to anti-angiogenic treatment.

From the evidence that simultaneous inhibition of EGFR and VEGFR leads to better target angiogenesis, a phase III trial tested the use of bevacizumab added to the association gemcitabine-erlotinib. Three hundred and one PDAC patients were randomly assigned to receive gemcitabine $(1,000 \mathrm{mg} / \mathrm{m}(2) /$ week $)$, erlotinib (100 mg/day), with or without bevacizumab (5 mg/ kg every 2 weeks). Despite a good safety profile and a better significant PFS (HR $0.73 ; P=.0002)$ of the triplet schedule, the addition of bevacizumab did not show a statistically significant improvement in terms of OS (7.1 and 6.0 months in the bevacizumab and placebo arms, respectively, HR 0.89; $P=$.2087) [57]. Similarly negative results were achieved in phase III trials using

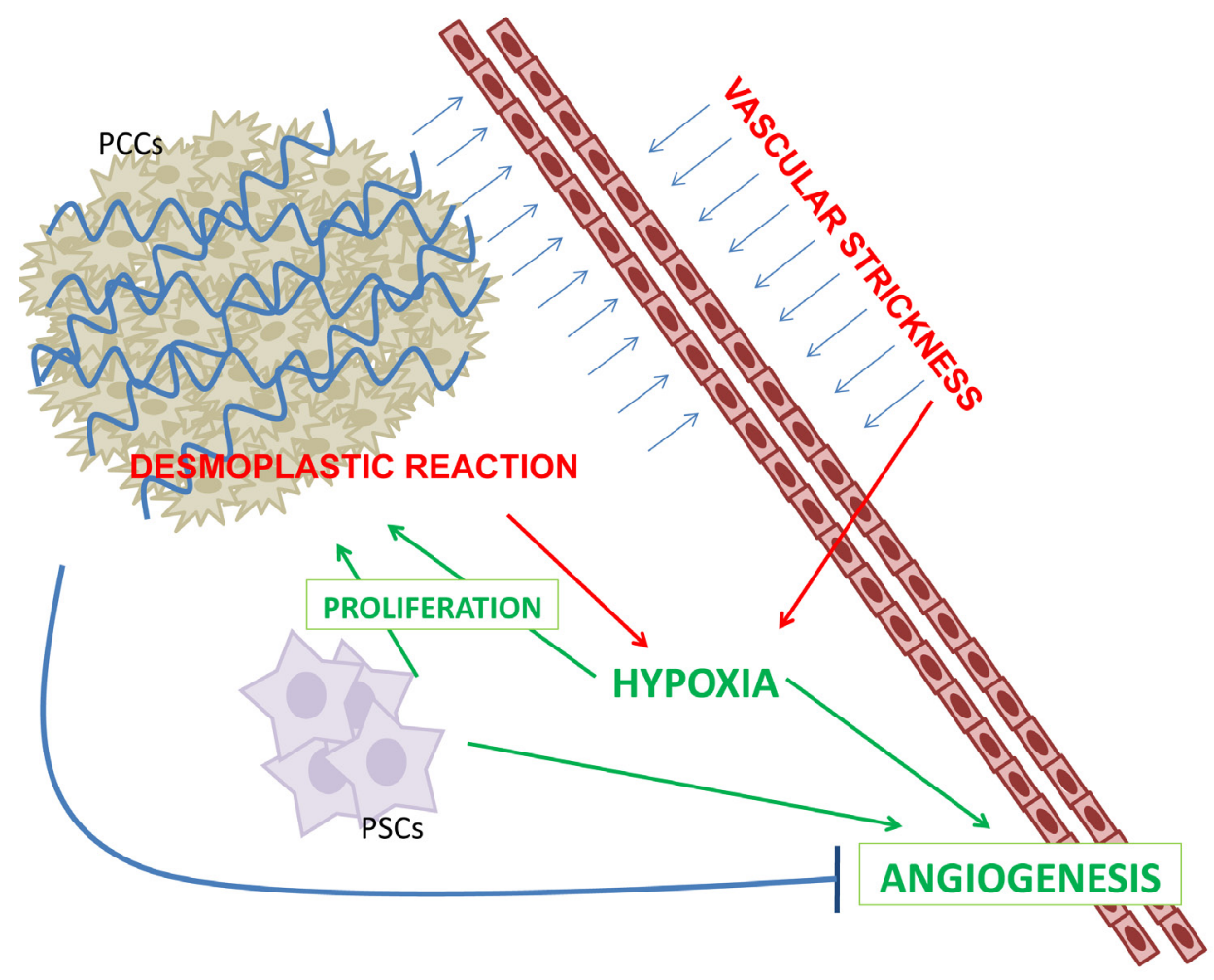

Figure 1: PDAC is characterized by a robust fibro-inflammatory response, namely desmoplastic reaction (DR). DR is the result of a complex interplay between pancreatic stellate cells (PSCs) and pancreatic cancer cells (PCCs). DR increased vascular strickness inducing hypoxia. Angiogenesis is both inhibited by DC and is enhanced by PSCs and hypoxia. 
combination of gemcitabine with anti-angiogenic agents such as axitinib [58], sorafenib [59], and ZIV-aflibercept [60]. In a phase II randomized trial, sunitinib , a tyrosine kinases inhibitor, compared to observation alone showed a PFS at six months of $22.2 \%$ and $3.6 \%$, a 2 years OS of $22.9 \%$ and $7.1 \%$, respectively, in the maintenance therapy after a gemcitabine -based first line [61]. Even so, a not significant superiority was achieved for the combination of Sunitinib and Gemcitabine in a randomized phase II trial in first line locally advanced or metastatic PDAC [62].

Moreover, Elpamotide, a peptide VEGFR-2 vaccine inducing a cellular immune response against VEGFR-2 expressing endothelial cells, did not improved mOS or PFS compared to gemcitabine alone, although the subgroup that showed severe side effects at the injection site apparently had a better outcome [63]. Probably the failure of anti-angiogenesis could depend on the absence of predictors of response, moreover, only $35 \%$ of PDAC seems to have an angiogenic phenotype [34, 64]. Ramucirumab, a recombinant fully human monoclonal antibody directed against human VEGFR-2, is under investigation in a phase II study, evaluating the efficacy and safety of FOLFIRINOX plus ramucirumab (Arm A) vs. FOLFIRINOX plus placebo (Arm B) in 94 subjects with advanced pancreatic cancer [65].

As mentioned above in the pre-clinical studies, lack of response may derive from high interstitial pressures and collapse of tumor vasculature. In fact, targeting stromal microenvironment elements could be an efficient therapeutic strategy in addition to classical and new chemoterapic agents [1]. The possible therapeutic role of PEGPH20, has been recently investigated in a randomized phase II trial. The study enrolled untreated patients with metastatic PDAC to receive nab-paclitaxel and gemcitabine (nab-paclitaxel $125 \mathrm{mg} / \mathrm{m}^{2}$ plus gemcitabine $1000 \mathrm{mg} / \mathrm{m}^{2}$ given IV x1/week $3 / 4$ weeks per cycle) combined with PEGPH20 (3ug/kg IV x 2/week for cycle 1 and weekly for cycle 2 and beyond, PAG) or placebo (AG). Following an initial clinical withdrawal for the evidence of several thromboembolic events $(29 \%$ and $15 \%$ for PAG and AG, respectively) the trial was started again with a prevention treatment with low molecular weight heparin, and concluded that in hyaluronan-high expression patients receiving $\mathrm{PAG}$ and $\mathrm{AG}$, the ORR was $52 \%$ vs $24 \%$ respectively $(P=.038)$, while there was no difference in $37 \%$ vs $38 \%$ hyaluronan-low expression patients. Moreover PFS was increased in patients with hyaluronanhigh expression, 9.2 and 4.3 for PAG and AG, respectively, and a there was a positive trend in OS [66]. On the basis of these results, a phase III trial of PAG has been started [67]. Based on encouraging preclinical data in Hedgehog signal role inhibition in tumor-associated stroma [51], IPI-926, an oral Hedgehog inhibitor, was evaluated in combination with FOLFIRINOX (5-fluorouracil, leucovorin, irinotecan, oxaliplatin) in a multicenter phase Ib study. Patients were treated with once-daily IPI-926 plus FOLFIRINOX at $3+3$ dose escalation design. The combination was generally well tolerated, with common treatment-related adverse events such as liver function test abnormalities, neuropathy, nausea/vomiting, and diarrhea. Patients presented a promising ORR of $67 \%$, with evident decline of CA19-9 levels [68]. Unfortunately, a phase II trial of IPI-926 plus gemcitabine was closed early due to an initial detrimental effect of this combination [69]. Furthermore, the MMP inhibitor marimastat was tested in patients with PDAC, based on the data that aberrant MMP expression is observed in this neoplasm. Bramhall et al. designed a phase III randomised study on 239 PDAC patients to compare orally administered marimastat in combination with gemcitabine to gemcitabine alone. There was no significant difference in OS between combination and gemcitabine plus placebo arm $(P=0.95)$, with a 1 -year survival of $18 \%$ and $17 \%$, respectively. Also no significant advantage was seen in ORR (11 and $16 \%$ respectively), in PFS $(P=0.68)$ and in time to treatment failure $(P=0.70)$ between the treatment arms [70].

In the future, the PDAC patients will be selected for the use of anti-angiogenic therapy through the angiogenetic signature. Moreover, the target of stroma through Hedgehog inhibitors or hyaluronidase enzymes together with actual standard therapies will plays a key role in the treatment of this malignancy. The main clinical trials are in progress are summarized in Table 1.

\section{CONCLUDING REMARKS}

The hypothesis that the peculiar stroma is responsible of chemoresistance in PDAC explains the low efficacy of anti-angiogenic agents in PDAC treatment. On the other hand, this biological property of PDAC microenvironment has led to suggest the depletion of tumor stroma as a strategy for PDAC treatment. However, this approach seems contradictory because in some GEMM studies stromal depletion with increased tumor vascularity and drug diffusion resulted efficacious, resulting in increasing survival. In the meantime, other studies have demonstrated that increased vasculature correlates with disease progression. In this context, strategies aimed to achieve a more precise and efficacious modulation of desmoplasia and tumor vascularity in PDAC are necessary.

\section{CONFLICTS OF INTEREST}

All Authors declare the absence of conflict of interest.

\section{REFERENCES}

1. Provenzano PP, Cuevas C, Chang AE, Goel VK, Von Hoff DD, Hingorani SR. Enzymatic targeting of the stroma ablates physical barriers to treatment of pancreatic ductal 
adenocarcinoma. Cancer Cell. 2012; 21(3): 418-29. doi: 10.1016/j.ccr.2012.01.007.

2. Büchler P, Reber HA, Büchler M, Shrinkante S, Büchler MW, Friess H, Semenza GL, Hines OJ. Hypoxia-inducible factor 1 regulates vascular endothelial growth factor expression in human pancreatic cancer. Pancreas. 2003; 26(1): 56-64.

3. Shibaji T, Nagao M, Ikeda N, Kanehiro H, Hisanaga M, Ko S, Fukumoto A, Nakajima Y. Prognostic significance of HIF-1 alpha overexpression in human pancreatic cancer. Anticancer Research. 2003;23(6C): 4721-4727.

4. Jacobetz MA, Chan DS, Neesse A, Bapiro TE, Cook N, Frese KK, Feig C, Nakagawa T, Caldwell ME, Zecchini HI, Lolkema MP, Jiang P, Kultti A, et al. Hyaluronan impairs vascular function and drug delivery in a mouse model of pancreatic cancer. Gut. 2013; 62(1): 112-20. doi: 10.1136/ gutjnl-2012-302529.

5. Kindler HL1, Niedzwiecki D, Hollis D, Sutherland S, Schrag D, Hurwitz H, Innocenti F, Mulcahy MF, O'Reilly E, Wozniak TF, Picus J, Bhargava P, Mayer RJ, et al. Gemcitabine plus bevacizumab compared with gemcitabine plus placebo in patients with advanced pancreatic cancer: phase III trial of the Cancer and Leukemia Group B (CALGB 80303). J Clin Oncol. 2010; 28(22): 3617-22.

6. Itakura J, Ishiwata $\mathrm{T}$, Friess $\mathrm{H}$, Fujii H, Matsumoto $\mathrm{Y}$, Büchler MW, Korc M. Enhanced expression of vascular endothelial growth factor in human pancreatic cancer correlates with local disease progression. Clin Cancer Res. 1997; 3(8): 1309-16.

7. Ikeda N, Adachi M, Taki T, Huang C, Hashida H, Takabayashi A, Sho M, Nakajima Y, Kanehiro H, Hisanaga M, Nakano H, Miyake M. Prognostic significance of angiogenesis in human pancreatic cancer. $\mathrm{Br} \mathrm{J}$ Cancer. 1999; 79(9-10): 1553-63.

8. Seo Y, Baba H, Fukuda T, Takashima M, Sugimachi K. High expression of vascular endothelial growth factor is associated with liver metastasis and a poor prognosis for patients with ductal pancreatic adenocarcinoma. Cancer. 2000; 88(10): 2239-45.

9. Niedergethmann M, Hildenbrand R, Wostbrock B, Hartel M, Sturm JW, Richter A, Post S. High expression of vascular endothelial growth factor predicts early recurrence and poor prognosis after curative resection for ductal adenocarcinoma of the pancreas. Pancreas. 2002; 25(2): 122-9.

10. Ammendola M, Sacco R, Marech I, Sammarco G, Zuccalà V, Luposella M, Patruno R, Giordano M, Ruggieri E, Zizzo N, Gadaleta CD, Ranieri G. Microvascular density and endothelial area correlate with $\mathrm{Ki}-67$ proliferative index in surgically-treated pancreatic ductal adenocarcinoma patients. Oncol Lett. 2015; 10(2) : 967-971.

11. Armstrong T, Packham G, Murphy LB, Bateman AC, Conti JA, Fine DR, Johnson CD, Benyon RC, Iredale JP. Type I collagen promotes the malignant phenotype of pancreatic ductal adenocarcinoma. Clin Cancer Res. 2004; 10(21):
7427-37.

12. Mahadevan D, Von Hoff DD. Tumor-stroma interactions in pancreatic ductal adenocarcinoma. Mol Cancer Ther. 2007; 6(4): 1186-97.

13. Heinemann V, Reni M, Ychou M, Richel DJ, Macarulla $\mathrm{T}$, Ducreux M. Tumour-stroma interactions in pancreatic ductal adenocarcinoma: rationale and current evidence for new therapeutic strategies. Cancer Treat Rev. 2014; 40(1): 118-28. doi: 10.1016/j.ctrv.2013.04.004.

14. Erkan M, Reiser-Erkan C, Michalski CW, Deucker S, Sauliunaite D, Streit S, Esposito I, Friess H, Kleeff J. Cancer-stellate cell interactions perpetuate the hypoxiafibrosis cycle in pancreatic ductal adenocarcinoma. Neoplasia. 2009; 11(5):497-508.

15. Masamune A, Kikuta K, Watanabe T, Satoh K, Hirota M, Shimosegawa T. Hypoxia stimulates pancreatic stellate cells to induce fibrosis and angiogenesis in pancreatic cancer. Am J Physiol Gastrointest Liver Physiol. 2008; 295(4): G709-17. doi: 10.1152/ajpgi.90356.2008.

16. Erickson LA, Highsmith WE Jr, Fei P, Zhang J. Targeting the hypoxia pathway to treat pancreatic cancer. Drug Des Devel Ther. 2015; 9: 2029-31. doi: 10.2147/DDDT.S80888. eCollection 2015.

17. Korc M. Pathways for aberrant angiogenesis in pancreatic cancer. Mol Cancer. 2003 7;2:8.

18. Hezel AF, Kimmelman AC, Stanger BZ, Bardeesy N, Depinho RA. Genetics and biology of pancreatic ductal adenocarcinoma. Genes Dev. 2006; 20(10):1218-49.

19. Ribatti D. Mast cells in lymphomas. Crit Rev Oncol Hematol. 2016 May;101:207-12. doi: 10.1016/j. critrevonc.2016.03.016.

20. Guidolin D, Marinaccio C, Tortorella C, Annese T, Ruggieri S, Finato N, Crivellato E, Ribatti D. Non-random spatial relationships between mast cells and microvessels in human endometrial carcinoma. Clin Exp Med. 2016 Feb 17.

21. Ribatti D, Finato N, Crivellato E, Guidolin D, Longo V, Mangieri D, Nico B, Vacca A, Beltrami CA. Angiogenesis and mast cells in human breast cancer sentinel lymph nodes with and without micrometastases. Histopathology. 2007; 51(6):837-42.

22. Esposito I, Menicagli M, Funel N, Bergmann F, Boggi U, Mosca F, Bevilacqua G, Campani D. Inflammatory cells contribute to the generation of an angiogenic phenotype in pancreatic ductal adenocarcinoma. J Clin Pathol. 2004; 57(6):630-6.

23. Karamitopoulou E, Shoni M, Theoharides TC. Increased number of non-degranulated mast cells in pancreatic ductal adenocarcinoma but not in acute pancreatitis. Int $\mathrm{J}$ Immunopathol Pharmacol. 2014; 27(2): 213-20.

24. Strouch MJ, Cheon EC, Salabat MR, Krantz SB, Gounaris E, Melstrom LG, Dangi-Garimella S, Wang E, Munshi HG, Khazaie K, Bentrem DJ. Crosstalk between mast cells and pancreatic cancer cells contributes to pancreatic tumor progression. Clin Cancer Res. 2010; 16(8): 2257-65. doi: 


\subsection{8/1078-0432.CCR-09-1230.}

25. Chang DZ, Ma Y, Ji B, Wang H, Deng D, Liu Y, Abbruzzese JL, Liu YJ, Logsdon CD, Hwu P. Mast cells in tumor microenvironment promotes the in vivo growth of pancreatic ductal adenocarcinoma. Clin Cancer Res. 2011; 17(22): 7015-23. doi: 10.1158/1078-0432.CCR-11-0607.

26. Theoharides TC et al. Mast cells and pancreatic cancer. N Engl J Med. 2008 Apr 24;358(17):1860-1. doi: 10.1056/ NEJMcibr0801519.

27. de Souza Junior DA, Santana AC, da Silva EZ, Oliver C, Jamur MC. The Role of Mast Cell Specific Chymases and Tryptases in Tumor Angiogenesis. Biomed Res Int. 2015; 2015:142359. doi: 10.1155/2015/142359.

28. Ammendola M, Sacco R, Sammarco G, Donato G, Zuccalà V, Luposella M, Patruno R, Marech I, Montemurro S, Zizzo N, Gadaleta CD, Ranieri G. Mast cells density positive to tryptase correlates with angiogenesis in pancreatic ductal adenocarcinoma patients having undergone surgery. Gastroenterol Res Pract. 2014; 2014:951957. doi: 10.1155/2014/951957.

29. Ma Y, Hwang RF, Logsdon CD, Ullrich SE. Dynamic mast cell-stromal cell interactions promote growth of pancreatic cancer. Cancer Res. 2013; 73(13): 3927-37. doi: 10.1158/0008-5472.CAN-12-4479.

30. Thomas H. Pancreatic cancer: Infiltrating macrophages support liver metastasis. Nat Rev Gastroenterol Hepatol. 2016. doi: 10.1038/nrgastro.2016.71.

31. Schmid MC, Avraamides CJ, Foubert P, Shaked Y, Kang SW, Kerbel RS, Varner JA. Combined blockade of integrin$\alpha 4 \beta 1$ plus cytokines SDF- $1 \alpha$ or IL- $1 \beta$ potently inhibits tumor inflammation and growth. Cancer Res. 2011; 71(22): 6965-75. doi: 10.1158/0008-5472.CAN-11-0588.

32. Wang X, Liu Y, Ren H, et al. Polymorphisms in the hypoxia-inducible factor- $1 \alpha$ gene confer susceptibility to pancreatic cancer. Cancer Biol Ther. 2011; 12(5): 383-387.

33. Kobayashi H1, Lin PC.Angiopoietin/Tie2 signaling, tumor angiogenesis and inflammatory diseases. Front Biosci. 2005; 10: 666-74.

34. Craven KE, Gore J, Wilson JL, Korc M. Angiogenic gene signature in human pancreatic cancer correlates with TGFbeta and inflammatory transcriptomes. Oncotarget. 2016 ;7(1): 323-41. doi: 10.18632/oncotarget.6345.

35. Yasutome M, Gunn J, Korc M. Restoration of Smad4 in BxPC3 Pancreatic Cancer Cells Attenuates Proliferation without Altering Angiogenesis. Clin Exp Metastasis. 2005; 22: 461-473.

36. Brunetti O, Russo A, Scarpa A, Santini D, Reni M, Bittoni A, Azzariti A, Aprile G, Delcuratolo S, Signorile M, Gnoni A, Palermo L, Lorusso V, et al. MicroRNA in pancreatic adenocarcinoma: predictive/prognostic biomarkers or therapeutic targets? Oncotarget. 2015; 6(27): 23323-41. doi: 10.18632/oncotarget.4492.

37. Mace TA, Collins AL, Wojci SE, Croce CM, Lesinski GB, Bloomston M. Hypoxia induces the overexpression of
microRNA-21 in pancreatic cancer cells. J Surg Res. 2013; 184:855-86.

38. Sabatel C, Malvaux L, Bovy N, Deroanne C, Lambert V, Gonzalez ML, Colige A, Rakic JM, Noël A, Martial JA, Struman I. MicroRNA-21 exhibits antiangiogenic function by targeting RhoB expression in endothelial cells. PLoS One. 2011; 10;6(2):e16979.

39. Sicard F, Gayral M, Lulka H, Buscail L, Cordelier P. Targeting miR-21 for the therapy of pancreatic cancer. Mol Ther. 2013;21:986-94.

40. Li L, Li B, Chen D, Liu L, Huang C, Lu Z, Lun L, Wan X . miR139 and miR200c regulate pancreatic cancer endothelial cell migration and angiogenesis. Oncol Rep. 2015; 34(1): 518. doi: 10.3892/or.2015.3945.

41. Luo J, Guo P, Matsuda K, Truong N, Lee A, Chun C, Cheng SY, Korc M. Pancreatic cancer cell-derived vascular endothelial growth factor is biologically active in vitro and enhances tumorigenicity in vivo, Int. J. Cancer. 2001; 92 (3):361-369.

42. Hoshida T, Sunamura M, Duda DG, Egawa S, Miyazaki S, Shineha R, Hamada H, Ohtani H, Satomi S, Matsuno $\mathrm{S}$. Gene therapy for pancreatic cancer using an adenovirus vector encoding soluble fit-1 vascular endothelial growth factor receptor, Pancreas. 2002; 25 (2): 111-121.

43. Fukasawa M, Korc M. Vascular endothelial growth factortrap suppresses tumorigenicity of multiple pancreatic cancer cell lines, Clin. Cancer Res. 2004; 10 (10): 3327-3332.

44. Nagaraju GP, Zhu S, Ko JE, Ashritha N, Kandimalla R, Snyder JP, Shoji M, El-Rayes BF. Antiangiogenic effects of a novel synthetic curcumin analogue in pancreatic cancer. Cancer Lett. 2015; 357(2): 557-65. doi: 10.1016/j. canlet.2014.12.007.

45. Bai R, Ding T, Zhao J, Liu S, Zhang L, Lan X, Yu Y, Yin L. The effect of PI3K inhibitor LY294002 and gemcitabine hydrochloride combined with ionizing radiation on the formation of vasculogenic mimicry of Panc-1 cells in vitro and in vivo. Neoplasma. 2016; 63(1): 80-92. doi: 10.4149/ neo_2016_010.

46. Guo JQ, Zheng QH, Chen H, Chen L, Xu JB, Chen MY, Lu D, Wang ZH, Tong HF, Lin S. Ginsenoside Rg3 inhibition of vasculogenic mimicry in pancreatic cancer through downregulation of VE-cadherin/EphA2/MMP9/MMP2 expression. Int J Oncol. 2014; 45(3): 1065-72. doi: 10.3892/ ijo.2014.2500.

47. Hingorani SR, Wang L, Multani AS, Combs C, Deramaudt TB, Hruban RH, Rustgi AK, Chang S, Tuveson DA. Cancer Cell. 2005; 7: 469.

48. Olson P, Chu GC, Perry SR, et al. Imaging guided trials of the angiogenesis inhibitor sunitinib in mouse models predict efficacy in pancreatic neuroendocrine but not ductal carcinoma. Proc Natl Acad Sci USA 2011;108:E1275e84.

49. Singh M, Lima A, Molina R, Hamilton P, Clermont AC, Devasthali V, Thompson JD, Cheng JH, Bou Reslan H, Ho CC, Cao TC, Lee CV, Nannini MA, et al. Assessing 
therapeutic responses in Kras mutant cancers using genetically engineered mouse models. Nat Biotechnol. 2010; 28: 585-593.

50. Bai X, Zhi X, Zhang Q, Liang F, Chen W, Liang C, Hu Q, Sun X, Zhuang Z, Liang T. Inhibition of protein phosphatase 2A sensitizes pancreatic cancer to chemotherapy by increasing drug perfusion via HIF-1 $\alpha$-VEGF mediated angiogenesis. Cancer Lett. 2014; 28;355(2): 281-7. doi: 10.1016/j.canlet.2014.09.048.

51. Olive KP, Jacobetz MA, Davidson CJ, Gopinathan A, McIntyre D, Honess D, Madhu B, Goldgraben MA, Caldwell ME, Allard D, Frese KK, Denicola G, Feig C, et al. Inhibition of Hedgehog signaling enhances delivery of chemotherapy in a mouse model of pancreatic cancer. Science. 2009; 324(5933):1457-61. doi: 10.1126/ science. 1171362 .

52. Rhim AD, Oberstein PE, Thomas DH, Mirek ET, Palermo CF, Sastra SA, Dekleva EN, Saunders T, Becerra CP, Tattersall IW, Westphalen CB, Kitajewski J, et al. Stromal elements act to restrain, rather than support, pancreatic ductal adenocarcinoma. Cancer Cell. 2014; 25(6): 735-47. doi: 10.1016/j.ccr.2014.04.021.

53. Özdemir BC, Pentcheva-Hoang T, Carstens JL, Zheng X, Wu CC, Simpson TR, Laklai H, Sugimoto H, Kahlert C, Novitskiy SV, De Jesus-Acosta A, Sharma P, Heifari $\mathrm{P}$, et al. Depletion of carcinoma-associated fibroblasts and fibrosis induces immunosuppression and accelerates pancreas cancer with reduced survival. Cancer Cell. 2014;25(6):719-34. doi: 10.1016/j.ccr.2014.04.005.

54. Kindler HL, Friberg G, Singh DA, Locker G, Nattam S, Kozloff M, Taber DA, Karrison T, Dachman A, Stadler WM, Vokes EE. Phase II trial of bevacizumab plus gemcitabine in patients with advanced pancreatic cancer.J Clin Oncol. 2005; 23(31): 8033-40.

55. Roberts AS, Campa MJ, Gottlin EB, Jiang C, Owzar K, Kindler HL, Venook AP, Goldberg RM, O'Reilly EM, Patz EF Jr. Identification of potential prognostic biomarkers in patients with untreated, advanced pancreatic cancer from a phase 3 trial (Cancer and Leukemia Group B 80303). Cancer. 2012; 118(2):571-8.

56. Nixon AB1, Pang H, Starr MD, Friedman PN, Bertagnolli MM, Kindler HL, Goldberg RM, Venook AP, Hurwitz HI; Alliance for Clinical Trials In Oncology. Prognostic and predictive blood-based biomarkers in patients with advanced pancreatic cancer: results from CALGB80303 (Alliance). Clin Cancer Res. 2013; 19(24): 6957-66. doi: 10.1158/1078-0432.CCR-13-0926.

57. Van Cutsem E, Vervenne WL, Bennouna J, Humblet Y, Gill S, Van Laethem JL, Verslype C, Scheithauer W, Shang A, Cosaert J, Moore MJ. Phase III trial of bevacizumab in combination with gemcitabine and erlotinib in patients with metastatic pancreatic cancer. J Clin Oncol 2009; 27: 22312237.

58. Kindler HL, Ioka T, Richel DJ, Bennouna J, Létourneau R, Okusaka T, Funakoshi A, Furuse J, Park YS, Ohkawa
S, Springett GM, Wasan HS, Trask PC,.et al. Axitinib plus gemcitabine versus placebo plus gemcitabine in patients with advanced pancreatic adenocarcinoma: a double-blind randomized phase 3 study, Lancet Oncol. 2011; 12 (3): 256262, doi:10.1016/S1470-2045(11)70004-3.

59. Gonçalves A, Gilabert M, François E, Dahan L, Perrier H, Lamy R, Re D, Largillier R, Gasmi M, Tchiknavorian X, Esterni B, Genre D, Moureau-Zabotto L, et al.BAYPAN study: a double-blind phase III randomized trial comparing gemcitabine plus sorafenib and gemcitabine plus placebo in patients with advanced pancreatic cancer, Ann. Oncol. 2012; 23 (11): 2799-2805. doi:10.1093/annonc/mds135.

60. Rougier P, Riess H, Manges R, Karasek P, Humblet Y, Barone C, Santoro A, Assadourian S, Hatteville L, Philip PA. Randomised, placebo-controlled, double-blind, parallel-group phase III study evaluating aflibercept in patients receiving first-line treatment with gemcitabine for metastatic pancreatic cancer, Eur. J. Cancer 2013; 49 (12): 2633-2642, doi:10.1016/j.ejca.2013.04.002.

61. Reni M, Cereda S, Milella M, Novarino A, Passardi A, Mambrini A, Di Lucca G, Aprile G, Belli C, Danova M, Bergamo F, Franceschi E, Fugazza C, et al. Maintenance sunitinib or observation in metastatic pancreatic adenocarcinoma: a phase II randomised trial. Eur J Cancer. 2013; 49(17): 3609-15. doi: 10.1016/j.ejca.2013.06.041.

62. Bergmann L, Maute L, Heil G, Rüssel J, Weidmann E, Köberle D, Fuxius S, Weigang-Köhler K, Aulitzky WE, Wörmann B, Hartung G, Moritz B, Edler L, et al. A prospective randomised phase-II trial with gemcitabine versus gemcitabine plus sunitinib in advanced pancreatic cancer: a study of the CESAR Central European Society for Anticancer Drug Research-EWIV. Eur J Cancer. 2015; 51(1): 27-36. doi: 10.1016/j.ejca.2014.10.010.

63. Yamaue H, Tsunoda T, Tani M, Miyazawa M, Yamao K, Mizuno N, Okusaka T, Ueno H, Boku N, Fukutomi A, Ishii H, Ohkawa S.. Randomized phase II/III clinical trial of elpamotide for patients with advanced pancreatic cancer: PEGASUS-PC Study, Cancer Sci. 106 (7) (2015) 883-890, doi:10.1111/cas.12674.

64. Gore J, Craven KE, Wilson JL, Cote GA, Cheng M, Nguyen HV, Cramer HM, Sherman S, Korc M, ref TCGATCGA data and patient-derived orthotopic xenografts highlight pancreatic cancer-associated angiogenesis. Oncotarget. 2015; 6(10):7504-21. doi: 10.18632/oncotarget.3233.

65. NCT02581215 Phase II Randomized Trial of FOLFIRINOX +/- Ramucirumab in Advanced Pancreatic Cancer(Available at: https://clinicaltrials.gov/ct2/show/ NCT02581215).

66. Hingorani SR, Harris WP, Seery TE, Zheng L, Sigal D, Hendifar AE, Braiteh FS, Zalupski M, Baron AD, Bahary N, Wang-Gillam A, LoConte NK, Springett GM, Ritch PS, Hezel AF, Ma WW, Bathini VG,. Wu XW, Jiang P, Bullock AJ. J Clin Oncol 34, 2016 (suppl 4S; abstr 439).

67. NCT01839487: PEGPH20 Plus Nab-Paclitaxel Plus Gemcitabine Compared With Nab-Paclitaxel Plus Gemcitabine in Subjects With Stage IV Untreated 
Pancreatic Cancer (HALO-109-202). (Available at: https:// clinicaltrials.gov/ct2/show/NCT01839487).

68. Ko AH1, LoConte N, Tempero MA, Walker EJ, Kate Kelley R, Lewis S, Chang WC, Kantoff E, Vannier MW, Catenacci DV, Venook AP, Kindler HL A Phase I Study of FOLFIRINOX Plus IPI-926, a Hedgehog Pathway Inhibitor, for Advanced Pancreatic Adenocarcinoma. Pancreas. 2016; 45(3): 370-5.

69. http://www.businesswire.com/news/

home/20120127005146/en/Infinity-Reports-Update-Phase2-Study-Saridegib.

70. Bramhall SR, Schulz J, Nemunaitis J, Brown PD, Baillet M, Buckels JA. A double-blind placebo-controlled, randomised study comparing gemcitabine and marimastat with gemcitabine and placebo as first line therapy in patients with advanced pancreatic cancer. Br J Cancer 2002; 87: $161-1$. 